\title{
Energy Substrate Utilization in Infants Receiving Total Parenteral Nutrition with Different Glucose to Fat Ratios
}

\author{
J. L. BRESSON, P. NARCY, G. PUTET, C. RICOUR, C. SACHS, AND J. REY \\ Departments of Pediatrics, of Physiology, and CNRS UA 213, Hôpital des Enfants Malades, Paris, France
}

\begin{abstract}
As the fate of glucose and lipids infused during total parenteral nutrition is not well known in infants, we assessed energy substrate oxidation in 36 patients (mean age: $5.8 \pm 3.6 \mathrm{mo}$ ) on continuous total parenteral nutrition. The infants received isocaloric feeding regimens with nonprotein energy intakes either based on glucose alone (group 1) or on glucose-lipid mixtures providing $15 \%$ (group 2), 35\% (group 3), 50\% (group 4), or $70 \%$ (group 5) energy as fat for at least $6 \mathrm{~d}$ before glucose and fat oxidation rates were measured by open-circuit indirect calorimetry. Oxidative glucose disposal reached a maximal rate of $12.6 \pm 1.2 \mathrm{mg} / \mathrm{kg} \cdot \min (17.9 \pm 1.7 \mathrm{~g} / \mathrm{kg} \cdot \mathrm{d})$ in patients with the higher glucose infusion rates. Glucose infused in excess of maximal oxidative disposal was stored, mainly as fat. The increase in glucose infusion rate was paralleled by an increase in energy expenditure amounting to $16 \%$ of the energy value of infused glucose. Net fat oxidation was only observed in group $3(1.6 \pm 0.7 \mathrm{~g} / \mathrm{kg} \cdot \mathrm{d})$, $4(3.4 \pm 0.6 \mathrm{~g} / \mathrm{kg} \cdot \mathrm{d})$, and $5(3.9 \pm 0.4 \mathrm{~g} / \mathrm{kg} \cdot \mathrm{d})$ patients, with glucose infusion rates lower than $18.3 \mathrm{~g} / \mathrm{kg}$. d. However, there was no further increase in fat oxidation in group 5 as compared to group 4 patients, despite a further increase in fat intake, which only resulted in increasing fat deposition. Thus, fat infusion aiming at a significant contribution to coverage of energy expenditure requires that glucose oxidation be equal to or lower than maximal oxidative glucose disposal, hence that glucose infusion rates be lower than $18 \mathrm{~g} / \mathrm{kg}$. d. In these conditions, excessive fat deposition may be prevented by adapting fat infusion to fat oxidation capacity, which did not exceed $4 \mathrm{~g} / \mathrm{kg} \cdot \mathrm{d}$ in our patients. (Pediatr Res 25:645-648, 1989)
\end{abstract}

Abbreviations

TPN, total parenteral nutrition

GIR, glucose infusion rate

RQ, respiratory quotient

EE, energy expenditure

$\mathrm{VO}_{2}$, oxygen consumption

$\mathrm{VCO}_{2}$, carbon dioxide production

TPN has developed into a widely used mode of nutritional support for pediatric patients, yet there are many unanswered questions regarding the fate of infused substrates. For instance,

Received August 2, 1988; accepted December 22, 1988.

Correspondence to JL Bresson, M.D., Laboratoire de Nutrition, Département de Pédiatrie, Hôpital des Enfants Malades, 149 rue de Sèvres 75015 Paris, France.

Supported by Grant 86-3117E from the Caisse Nationale d'Assurance Maladie (CNAMTS), Grant 87/25 from the Nestle Nutrition Research Grant Program, and Grant 86/126 from the Fondation Française pour la Nutrition.
TPN for infants and children provides most of the energy as glucose, although it is not precisely known how much of the intravenously administered glucose is oxidized (1). Such information would be useful to determine the optimal glucose infusion rate in clinical settings, as the adverse effects of glucosebased TPN have been related, in adults, to excessive glucose infusion rates (2). Substitution of part of glucose calories with intravenous fat could reduce the undesirable effects reported with glucose-based TPN and even improve nitrogen balance (3). However, little information is available in the pediatric age about fat utilization (1), particularly regarding the possible adverse effect of simultaneous glucose infusion on the oxidation of infused fat (4).

Therefore, we assessed glucose and fat utilization in infants during the infusion of five isocaloric TPN regimes differing in their carbohydrate to fat ratios.

\section{MATERIALS AND METHODS}

Patients. Of 40 infants on continuous TPN entered in the study, measurements were completed in 36 cases; 33 received TPN for medical gastrointestinal diseases. Enteropathogenic bacteria were isolated from the stools of eight infants with severe diarrhea, and history and clinical course were considered compatible with the diagnosis of infectious diarrhea in 18 others, although microbiologic assays were not conclusive. Five infants received TPN because of a severe diarrhea caused by allergy to cow's milk. TPN had been undertaken in these cases because either malnutrition or infection were initially present as complicating factors. Two infants received TPN because of a suspected necrotizing enterocolitis; three others received TPN after surgical procedures for congenital abnormalities of the gastrointestinal tract. Mean age (mean \pm SD) was $5.8 \pm 3.6$ mo (range 2-17 mo), study wt $5 \pm 1 \mathrm{~kg}(3.6-8.2 \mathrm{~kg})$, with an actual wt to expected wt for height ratio of $93 \pm 7 \%(76-110 \%)$. At the time of the study, all patients were on stable TPN for more than $3 \mathrm{wk}$ and steadily growing $(6.5 \pm 1.8 \mathrm{~g} / \mathrm{kg} \cdot \mathrm{d})$. Infants were in good clinical condition and antimicrobial therapy, when initially required, had been discontinued. Patients with infectious or metabolic diseases and inflammatory syndromes were excluded from the study. The design of the study was reviewed by the INSERM ad hoc committee. Infants entered the study after a formal, informed consent was obtained from the parents.

$T P N$ regimes. Nitrogen was provided as a crystalline amino acid solution (Primène, Cernep, Paris, France) and nonprotein energy intake was either based on glucose alone (group $1 ; n=8$ ) or on glucose-lipid (Intralipid, KB Vitrum, Stockholm, Sweden) mixtures providing about $15 \%$ (group $2 ; n=7$ ), $35 \%$ (group 3; $n=7$ ), $50 \%$ (group $4 ; n=8$ ) and $70 \%$ (group $5 ; n=6$ ) nonprotein energy as fat. Regimes were supplemented with L-carnitine (50 $\mathrm{mg} / \mathrm{kg} \cdot \mathrm{d}$ ) to avoid the adverse effects of any possible carnitine deficiency on fat oxidation measurements. Patients were ran- 
domly assigned to one of these regimens. The characteristics of the different groups are summarized in Table 1, and the protein and nonprotein energy intakes in Table 2 . Minerals, trace elements and vitamins were provided according to recommended intakes (1). All nutrients were concurrently delivered through a central line, by continuous infusion over $24 \mathrm{~h}$. Feeding regimens were kept constant for at least $6 \mathrm{~d}$ before measurements were performed. Meanwhile, urine was repeatedly checked for glucose and ketone bodies (KetoDiabur test, Boehringer, Mannheim, Federal Republic of Germany) and blood glucose and electrolytes assessed every $3 \mathrm{~d}$.

Indirect calorimetry. $\mathrm{VO}_{2}$ and $\mathrm{VCO}_{2}$ were continuously measured for $12 \mathrm{~h}$ by open-circuit indirect calorimetry, using a ventilated hood system. Oxygen concentration was assessed by a differential paramagnetic analyser (Klogor, Lannion, France) and carbon dioxide concentration by an infrared analyzer (Beckman Instruments Inc., Anaheim, CA). Gas flow was measured using a linear mass flow meter (Setaram, Lyon, France). Raw data were continuously recorded on a potentiometric chart recorder (Linseis, Selb, Federal Republic of Germany) and on floppy discs. Gas exchange was calculated as the product of gas flow times differences in oxygen and carbon dioxide concentrations between inlet and outlet of the ventilated hood. Corrections were made for effects of RQ on gas flow measurements (5). Before each measurement, the system was calibrated by nitrogen dilution tests (6) and gravimetric gas standards and regularly checked by burning butane under standard conditions. Recovery for $\mathrm{O}_{2}$ and $\mathrm{CO}_{2}$ were $97 \pm 1.8 \%$ and $98.4 \pm 2 \%$, respectively, and RQ was $0.618 \pm 0.007(n=12)$. During the studies, urine was collected using adhesive rubber bag collectors to determine urinary nitrogen excretion.

Net substrate oxidation rates were calculated according to published methods $(7,8)$, and the results were expressed as $\mathrm{g} / \mathrm{kg}$ body wt/d. The following constants were used: $6.25 \mathrm{~g}$ of protein are oxidized to produce $1 \mathrm{~g}$ urea nitrogen and $966 \mathrm{~mL} \mathrm{O}_{2}$ required to oxidize $1 \mathrm{~g}$ of protein in this way producing $773.9 \mathrm{~mL} \mathrm{CO}$. Oxygen consumed is $2019.3 \mathrm{~mL} / \mathrm{g}$ of fat with $\mathrm{RQ}=0.707$ and $745.8 \mathrm{~mL} / \mathrm{g}$ glucose, with a $\mathrm{RQ}=1$. When nonprotein $\mathrm{RQ}$ exceeded 1 , fat oxidation assumed a negative value corresponding to net fat synthesis (7). In this condition, the value for carbohydrate oxidation overestimates the conversion of glucose to $\mathrm{CO}_{2}$ by the amount of glucose converted to lipids $(7,8)$. This amount was calculated from nonprotein $\mathrm{O}_{2}$ consumed and $\mathrm{CO}_{2}$ produced, according to Lillioja et al. (9). This value was subtracted from net glucose oxidation to obtain the oxidative glucose disposal rate. Glucose storage as glycogen and fat was calculated by subtracting oxidative glucose disposal rate from GIR. Fat deposition was obtained from fat infusion rate minus net fat oxidation rate. EE was calculated from gaseous exchange using the nonprotein RQ (7) and results expressed as $\mathrm{kcal} / \mathrm{kg}$ body wt/d.

Biochemical assays. Before beginning calorimetric measurements, blood samples were drawn for glucose and triglyceride determinations. Plasma insulin was measured in group 1 and group 4 patients. Blood glucose was assayed by the glucose oxidase method (10), triglycerides by enzyme assay (11), and plasma insulin by RIA (12) Total urinary nitrogen was determined by the micro-Kjeldahl method (13).

Statistical analysis. Results are expressed as mean \pm SD. Analysis of variance and Tukey studentized range method (14) were used for comparisons between groups. Analysis of covariance was used to assess the effect of cofactors, and the equality of adjusted means was tested using the Bonferroni corrected $t$ test. Correlations were product-moment correlations. Linear regression was applied when appropriate. All calculations were performed using the standard BMDP program (15).

\section{RESULTS}

There was no significant difference in height, body wt, and body wt to expected wt for height ratio between the different groups (Table 1). Although glucose and fat infusion rates significantly differed between groups $(p<0.01)$, energy and protein intakes were comparable (Table 2). Plasma glucose was slightly but significantly higher in groups 1 and 2 than in group 5 (Table 3 ). None of the patients had glucosuria or ketonuria. Plasma insulin was higher in group 1 than in group 4 patients $(p<0.01)$. Plasma triglycerides concentrations were significantly different between group 5 and group 1 and 4 patients $(p<0.05)$. The difference did not reach significance between group 5 and group 2 and 3 patients $(0.05<p<0.1)$ probably because of two missing values in groups 2 and 3 .

Net fat synthesis was observed in group $1(-2.2 \pm 0.6 \mathrm{~g} / \mathrm{kg} \cdot \mathrm{d})$ and in group 2 patients $(-0.85 \pm 0.4 \mathrm{~g} / \mathrm{kg} \cdot \mathrm{d}$ ) (Fig 1). Net fat synthesis accounted for $6.4 \pm 1.6$ and $2.3 \pm 1.2 \mathrm{~g} / \mathrm{kg} \cdot \mathrm{d}$ glucose converted to fat in group 1 and 2 patients, respectively. Net fat oxidation was observed in group $3(1.62 \pm 0.7 \mathrm{~g} / \mathrm{kg} \cdot \mathrm{d})$, group 4 $(3.4 \pm 0.6 \mathrm{~g} / \mathrm{kg} \cdot \mathrm{d})$, and group 5 patients $(3.9 \pm 0.42 \mathrm{~g} / \mathrm{kg} \cdot \mathrm{d})$ (Fig 1). Except between groups 4 and 5 , net fat oxidation differed

Table 1. Characteristics of groups studied

\begin{tabular}{|c|c|c|c|c|c|}
\hline & \multicolumn{5}{|c|}{ Group } \\
\hline & 1 & 2 & 3 & 4 & 5 \\
\hline No. of patients & 8 & 7 & 7 & 8 & 6 \\
\hline Age (mos) (range) & $\begin{array}{r}4.2 \pm 2 \\
(2-8)\end{array}$ & $\begin{array}{l}7.8 \pm 4 \\
(2.6-15)\end{array}$ & $\begin{array}{l}7.8 \pm 5 \\
(2.5-17)\end{array}$ & $\begin{array}{l}4.5 \pm 2 \\
(2.5-8)\end{array}$ & $\begin{array}{r}4.3 \pm 1 \\
(2-5)\end{array}$ \\
\hline Height $(\mathrm{cm})$ (range) & $\begin{array}{l}57 \pm 3 \\
(53-62)\end{array}$ & $\begin{array}{l}60 \pm 6 \\
(52-71)\end{array}$ & $\begin{array}{l}59 \pm 5 \\
(53-67)\end{array}$ & $\begin{array}{l}57 \pm 3 \\
(53-66)\end{array}$ & $\begin{array}{l}59 \pm 4 \\
(54-65)\end{array}$ \\
\hline Wt $(\mathrm{kg})$ (range) & $\begin{array}{l}4.8 \pm 0.7 \\
(4.2-5.8)\end{array}$ & $\begin{array}{l}5.3 \pm 1.6 \\
(3.8-8.2)\end{array}$ & $\begin{array}{c}4.8 \pm 0.8 \\
(4-6.2)\end{array}$ & $\begin{array}{l}4.6 \pm 0.7 \\
(4-6.2)\end{array}$ & $\begin{array}{c}5.4 \pm 1.3 \\
(4-7)\end{array}$ \\
\hline $\mathrm{Wt} /$ expected wt for ht ratio (\%) (range) & $\begin{array}{l}94 \pm 7 \\
(83-107)\end{array}$ & $\begin{array}{l}93 \pm 7 \\
(85-110)\end{array}$ & $\begin{array}{l}92 \pm 10 \\
(76-107)\end{array}$ & $\begin{array}{l}93 \pm 6 \\
(82-102)\end{array}$ & $\begin{array}{l}97 \pm 4 \\
(92-104)\end{array}$ \\
\hline
\end{tabular}

Table 2. Protein and energy intakes

\begin{tabular}{|c|c|c|c|c|c|}
\hline & \multicolumn{5}{|c|}{ Group } \\
\hline & 1 & 2 & 3 & 4 & 5 \\
\hline No. of patients & 8 & 7 & 7 & 8 & 6 \\
\hline Glucose infusion rate $(\mathrm{g} / \mathrm{kg} \cdot \mathrm{d})$ & $28.8 \pm 2.3$ & $24 \pm 1$ & $18.3 \pm 0.6$ & $13.5 \pm 0.5$ & $8.3 \pm 0.3$ \\
\hline Fat infusion rate $(\mathrm{g} / \mathrm{kg} \cdot \mathrm{d})$ & 0 & $1.5 \pm 0.2$ & $3.5 \pm 0.3$ & $5.5 \pm 0.3$ & $7.2 \pm 0.4$ \\
\hline Amino acid infusion rate $(\mathrm{g} / \mathrm{kg} \cdot \mathrm{d})$ & $2.8 \pm 0.1$ & $2.9 \pm 0.2$ & $2.8 \pm 0.2$ & $2.8 \pm 0.2$ & $2.7 \pm 0.2$ \\
\hline Nonprotein energy intake $(\mathrm{g} / \mathrm{kg} \cdot \mathrm{d})$ & $107.7 \pm 6$ & $105.9 \pm 5$ & $104.3 \pm 4$ & $106.8 \pm 4$ & $104.7 \pm 3$ \\
\hline
\end{tabular}


Table 3. Plasma glucose, triglyceride, and insulin concentrations*

\begin{tabular}{|c|c|c|c|c|c|}
\hline & \multicolumn{5}{|c|}{ Group } \\
\hline & 1 & 2 & 3 & 4 & 5 \\
\hline Plasma glucose $\mathrm{mmol} / \mathrm{liter}(n)$ & $\begin{array}{c}5.2 \pm 0.2 \dagger \\
(8)\end{array}$ & $\begin{array}{l}5 \pm 0.2 \ddagger \\
(7)\end{array}$ & $\begin{array}{c}4.8 \pm 0.3 \S \\
(7)\end{array}$ & $\begin{array}{c}4.8 \pm 0.3 \\
(8)\end{array}$ & $\begin{array}{c}4.6 \pm 0.2 \dagger \ddagger \\
(6)\end{array}$ \\
\hline Triglycerides $\mathrm{mmol} /$ liter $(n)$ & $\begin{array}{c}0.44 \pm 0.2 \dagger \\
(8)\end{array}$ & $\begin{array}{c}0.83 \pm 0.46 \\
(5)\end{array}$ & $\begin{array}{c}0.91 \pm 0.24 \\
(5)\end{array}$ & $0.94 \pm 0.38 \ddagger$ & $\begin{array}{c}1.6 \pm 0.8 \dagger \\
(6)\end{array}$ \\
\hline Insulin $\mu \mathrm{U} /$ mliter $(n)$ & $\begin{array}{c}26.6 \pm 2.7 \dagger \\
(8)\end{array}$ & & & $\begin{array}{c}9.8 \pm 2.1 \dagger \\
(8)\end{array}$ & \\
\hline
\end{tabular}

* Values sharing the same symbol differ at $0.05 \%$ level.

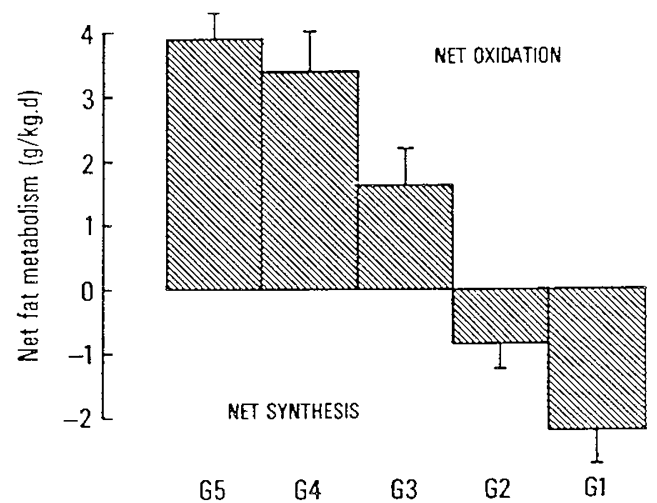

Fig. 1. Net fat oxidation and synthesis in the different experimental groups. Negative values indicate net fat synthesis and positive values indicate net fat oxidation (see "Materials and Methods"). Net fat oxidation rates differed significantly $(p<0.01)$, except between group 4 and 5 patients.

significantly between groups $(p<0.01)$. Net fat oxidation was inversely related to oxidative glucose disposal rate $(r=-0.91 ; p$ $<0.001)$. Fat infusion $(1.5 \pm 0.2 \mathrm{~g} / \mathrm{kg} \cdot \mathrm{d})$ to group 2 patients increased fat deposition rate $(2.3 \pm 0.4 \mathrm{~g} / \mathrm{kg} \cdot \mathrm{d})$ to the level of group 1 patients $(2.2 \pm 0.6 \mathrm{~g} / \mathrm{kg} \cdot \mathrm{d})$. There was no significant difference in fat deposition rates between group 2, 3 (1.9 \pm 0.6 $\mathrm{g} / \mathrm{kg} \cdot \mathrm{d})$, and 4 patients $(2.1 \pm 0.6 \mathrm{~g} / \mathrm{kg} \cdot \mathrm{d})$. A further increase in fat infusion rate in group 5 patients resulted in a higher fat deposition rate $(3.2 \pm 0.4 \mathrm{~g} / \mathrm{kg} \cdot \mathrm{d})$ than in group 4 patients $(\mathrm{p}<$ $0.01)$.

Oxidative glucose disposal rate increased from $6.8 \pm 0.2 \mathrm{~g} / \mathrm{kg}$. $\mathrm{d}$ in group 5 to $17.8 \pm 1.4 \mathrm{~g} / \mathrm{kg} \cdot \mathrm{d}$ in group 2 patients $(p<0.01)$ (Fig. 2). However, there was no further increase in oxidative glucose disposal rate in group 1 patients $(17.9 \pm 1.7 \mathrm{~g} / \mathrm{kg} \cdot \mathrm{d})$, as compared to group 2 patients, despite a further increase in GIR. Total glucose storage significantly increased from $1.4 \pm 1.8 \mathrm{~g} /$ $\mathrm{kg} \cdot \mathrm{d}$ in group 5 to $6.2 \pm 1.0$ in group $2(p<0.01)$ and further to $10.9 \pm 1.6 \mathrm{~g} / \mathrm{kg} \cdot \mathrm{d}$ in group 1 patients $(p<0.01)$. Glucose conversion to fat accounted for about $37 \%$ and $58 \%$ of the glucose stored in group 2 and 1 patients, respectively.

EE increased with increasing GIR $(r=0.62 ; p<0.001)$ and was $67.2 \pm 7,69.4 \pm 6,72 \pm 5,75.3 \pm 5$, and $78.4 \pm 7 \mathrm{kcal} / \mathrm{kg}$. $\mathrm{d}$ in group $5,4,3,2$, and 1 , respectively. EE was significantly lower in group 5 than in group $1(p<0.05)$. The increase in EE amounted to $16 \%$ of the energy value of infused glucose.

Analysis of covariance did not detect any significant effect of age, height, body wt and of body wt to expected wt for height ratio on the parameters measured in each group.

\section{DISCUSSION}

There was a steep increase in oxidative glucose disposal rate from group 5 to group 2 patients, as previously observed in response to increasing GIR (16). However, there was no further increase in oxidative glucose disposal rate in group 1 as compared

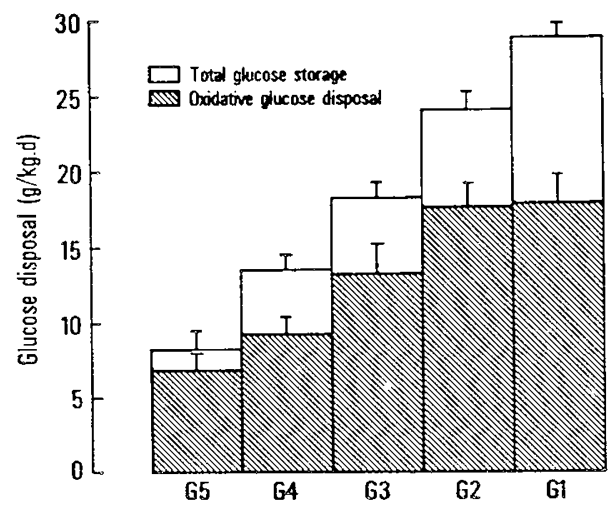

Fig. 2. Oxidative glucose disposal and total glucose storage in the different experimental groups. Oxidative glucose disposal rates differed significantly $(p<0.01)$, except between group 1 and 2 patients and between group 4 and 5 patients. Total glucose storage rates (as glycogen and fat) significantly differed $(p<0.01)$, except between group 2 and 3 patients and between group 3 and 4 patients.

to group 2 patients, despite a further increase in GIR, suggesting that oxidative glucose metabolism reached a maximal rate of $17.8-17.9 \mathrm{~g} / \mathrm{kg} \cdot \mathrm{d}(12.4-12.6 \mathrm{mg} / \mathrm{kg} \cdot \mathrm{min})$ with the higher glucose infusion rates. Determination of glucose oxidation in group 1 and 2 patients is not likely to be hampered by gluconeogenesis, as residual glucose production during high-dose glucose infusions is derived from glucose carbon cycling through the Cori cycle (17), which does not involve any net gas exchange (7). Similarly, underestimation of net fat synthesis is not likely in group 1 patients, as fat oxidation is suppressed by high glucose infusion rates (18).

A maximal oxidative glucose disposal rate has previously been demonstrated in adults, either by using indirect calorimetry (19) or ${ }^{13} \mathrm{C}$-labeled glucose infusions (17), but has not been reported yet in infants. The maximal oxidative glucose disposal rate in group 1 and 2 patients is considerably higher than the approximately $3 \mathrm{mg} / \mathrm{kg} \cdot \mathrm{min}$ in adults $(17,19)$, probably reflecting differences in relative metabolic rate. Indeed, we have indications from previous work (Bresson JL, Putet G, unpublished data) that maximal oxidative glucose disposal decreases with age, amounting to $8.9 \pm 1.4$ and $5.8 \pm 1 \mathrm{mg} / \mathrm{kg} \cdot \mathrm{min}$ at age 6 and $10 \mathrm{y}$, respectively.

Glucose infusion in excess of this maximal oxidative glucose disposal resulted, in our patients, in increasing glucose storage, particularly as fat. The high cost of the glucose processing was reflected by an increase in energy expenditure with increasing GIR, as previously observed (18). This may explain that metabolic rate in group 1 patients was higher than energy expenditure of normal infants with similar body height and wt (20), whereas it was comparable in group 5 patients.

Fat infusion to group 2 patients did not result in net fat oxidation but, in addition to net fat synthesis, increased fat deposition rate to the level of group 1 patients. Net fat oxidation was only achieved in group 3,4 , and 5 patients, with GIR equal to or lower than $18.3 \mathrm{~g} / \mathrm{kg} \cdot \mathrm{d}$. However, there was no significant 
increase in fat oxidation in group 5 as compared to group 4 patients, despite a further increase in fat intake which only increased fat retention rate. These results suggest that fat intake may not be the major determinant of fat oxidation during continuous infusion of glucose-lipid mixtures. This is supported by the absence of any significant change in fat oxidation rate, when energy intake is increased by varying only fat intake (16). The inverse relationship between net fat oxidation and oxidative glucose disposal, also reported in adults (9), is in agreement with Flatt's suggestion that fat oxidation is regulated by energy needs, rather than by fat intakes (21). The comparison of the data of Sauer et al. (22) to ours supports this hypothesis. Net fat oxidation was suppressed and net fat synthesis occurred when oxidative glucose disposal reached a maximal rate of $11 \pm 0.6 \mathrm{~g} / \mathrm{kg} \cdot \mathrm{d}$ in their newborn infants, whereas it was achieved with oxidative glucose disposal rates of $17.8 \pm 1.6 \mathrm{~g} / \mathrm{kg} \cdot \mathrm{d}$ in our patients. Net fat oxidation set points thus differed in the two populations by an amount of glucose-oxidized equivalent to $25.4 \mathrm{kcal} / \mathrm{kg} \cdot \mathrm{d}$, which is nearly equal to the difference in mean energy expenditure between the two groups of infants $(49.2 \pm 6$ and $73 \pm 7$ $\mathrm{kcal} / \mathrm{kg} \cdot \mathrm{d}$, respectively). This suggests that during glucose-lipid mixture infusions, fat oxidation is inversely related to the amount of glucose oxidized for the coverage of energy expenditure.

Calculations differing by the assumptions made about fat oxidation constants would not significantly alter these results. The difference would be less than $5 \%$ for both net fat synthesis in group 1 and net fat oxidation in group 5, if either pure palmitate or pure intralipid fatty acids were respectively assumed to be oxidized $(9,23)$. Although many of our patients were initially malnourished, at the time of the study their wt to expected wt for height ratios were within normal limits, and growth rate and metabolic rate were within the range of those of infants of comparable body height and wt $(20,24)$, suggesting that these results may be relevant to TPN implementation in normally nourished infants.

Thus, glucose intakes in excess of the maximal oxidative glucose disposal rate only result in glucose storage, particularly as fat. This might account for the extensive lipid deposition reported both in liver (2) and adipose tissue (25) after glucosebased TPN. The high cost of glucose storage as fat is reflected by an increase in energy expenditure. In these conditions, fat infusion further increases fat deposition, reflecting the fat metabolism trend toward storage (26). Fat infusion, together with high glucose infusion rates, is therefore not advisable, as it may result in very high fat retention rates and possibly fat overloading. Fat infusion aimed at a significant coverage of energy expenditure requires that glucose oxidation rates be lower than the maximal oxidative glucose disposal, hence that GIR be lower than $18 \mathrm{~g} / \mathrm{kg} \cdot \mathrm{d}$. In these conditions, energy expenditure is lower, and excessive fat deposition may be prevented by adapting fat infusion rate to fat oxidation capacity, which did not exceed $4 \mathrm{~g} / \mathrm{kg} \cdot \mathrm{d}$ in our patients.

Acknowledgment. The authors thank P. Landais (Laboratoire de Biostatistiques) for his help in data analysis.

\section{REFERENCES}

1. Zlotkin SH, Stallings VA, Pencharz PB 1985 Total parenteral nutrition in children. Pediatr Clin North Am 32:381-400

2. Stein TP, Mullen JL 1985 Hepatic fat accumulation in man with excess parenteral glucose. Nutr Res 5:1347-1351

3. Nose O, Tipton JR, Ament ME, Yabuuchi H 1987 Effect of the energy source on changes in energy expenditure, respiratory quotient and nitrogen balance during total parenteral nutrition in children. Pediatr Res 21:538-541

4. Waterhouse C, Baker N, Rostami H 1969 Effect of glucose ingestion on the metabolism of free fatty acids in human subjects. J Lipid Res 10:487-494

5. Lister G, Hoffman J, Rudolph AM 1974 Oxygen uptake in infants and children: a simple method for measurements. Pediatrics 53:656-662

6. Damask MC, Weissman C, Askanazi J, Hyman AI, Rosenbaum SH, Kinney JM 1982 A systematic method for validation of gas exchange measurements. Anesthesiology 57:213-218

7. Frayn KN 1983 Calculation of substrate oxidation rates in vivo from gaseous exchange. J Appl Physiol 55:628-634

8. Ben Porat M, Sideman S, Bursztein S 1983 Energy metabolism rate equation for fasting and postabsorptive subjects. Am J Physiol 244:R764-9

9. Lillioja S, Bogardus C, Mott DM, Kennedy AL, Knowler WC, Howard BV 1985 Relationship between insulin mediated glucose disposal and lipid metabolism in man. J Clin Invest 75:1106-1115

10. Huggett ASG, Nixon DA 1957 Use of glucose oxidase, peroxidase and Odianisidine in determination of blood and urinary glucose. Lancet 2:368370

11. Bucolo G, David H 1973 Quantitative determination of serum triglycerides by the use of enzyme. Clin Chem 19:476-82

12. Herbert V, Lau K, Gottlieb CW, Bleisher SJ 1965 Coated charcoal immunoassay of insulin. J Clin Endocrinol Metab 25:1375-1384

13. Ma TS, Zuazaga G 1942 Micro Kjeldahl determination of nitrogen: a new indicator and a rapid method. Indust Eng Chem 14:280-282

14. Scheffe H 1959 The analysis of variance. Wiley and Sons, New York, pp 5590

15. Dixon WJ 1985 BMDP statistical software. University of California Press, Berkeley

16. Putet G, Verellen G, Heim T, Smith JM, Swyer PR 1981 Energy intake and substrate utilisation during total parenteral nutrition in newborn. In: Wesdorp RIC, Soeters PB (eds) Clinical Nutrition ' 81 . Churchill-Livingstone,
Edinburgh, pp 63-70

17. Wolfe RR, Allsop JR, Burke JF 1979 Glucose metabolism in man: response to intravenous glucose infusion. Metabolism 28:210-220

18. Gil KM, Askanazi J, Elwyn DH, Gump FE, Kinney JM 1987 Energy expenditure after infusion of glucose based total parenteral nutrition. Am J Physiol 253:E135-E131

19. Defronzo RA, Jacot E, Jequier E, Maeder E, Wahren J, Felber JP 1981 The effect of insulin on the disposal of intravenous glucose. Diabetes 30:10001007

20. Wong WW, Butte NF, Garza C, Klein PD 1987 Energy expenditures of term infants determined by the doubly-labeled water method, indirect calorimetry and test-weighting. Pediatr Res 21(suppl):650(abstr)

21. Flatt JP, Ravussin E, Acheson KJ, Jéquier E 1985 Effects of dietary fat on postprandial substrate oxidation and on carbohydrate and fat balances. J Clin Invest 76:1019-1024

22. Sauer PJJ, Van Aerde JEE, Pencharz PB, Smith JM, Swyer PR 1986 Glucose oxidation rates in newborn infants measured with indirect calorimetry and (U-13C) glucose. Clin Sci 70:587-593

23. Livesey G, Elia M 1988 Estimation of energy expenditure, net carbohydrate utilization, and net fat oxidation and synthesis by indirect calorimetry: evaluation of errors with special reference to the detailed composition of fuels. Am J Clin Nutr 47:608-28

24. Hitchcock NE, Gracey M, Gilmour Al 1985 The growth of breast fed and artificially fed infants from birth to twelve months. Acta Paediatr Scand $74: 240-245$

25. Shike M, Russell D, Detsky AS, Harrison JE, McNeill KG, Shepherd FA, Feld $R$, Evans WK, Jeejeebhoy KN 1984 Changes in body composition in patients with small-cell lung cancer. The effect of total parenteral nutrition as an adjunct to chemotherapy. Ann Intern Med 101:303-309

26. Wene JD, Connor WE, DenBesten L 1975 The development of essential fatty acid deficiency in healthy men fed fat-free diets intravenously and orally. J Clin Invest 56:127-134 